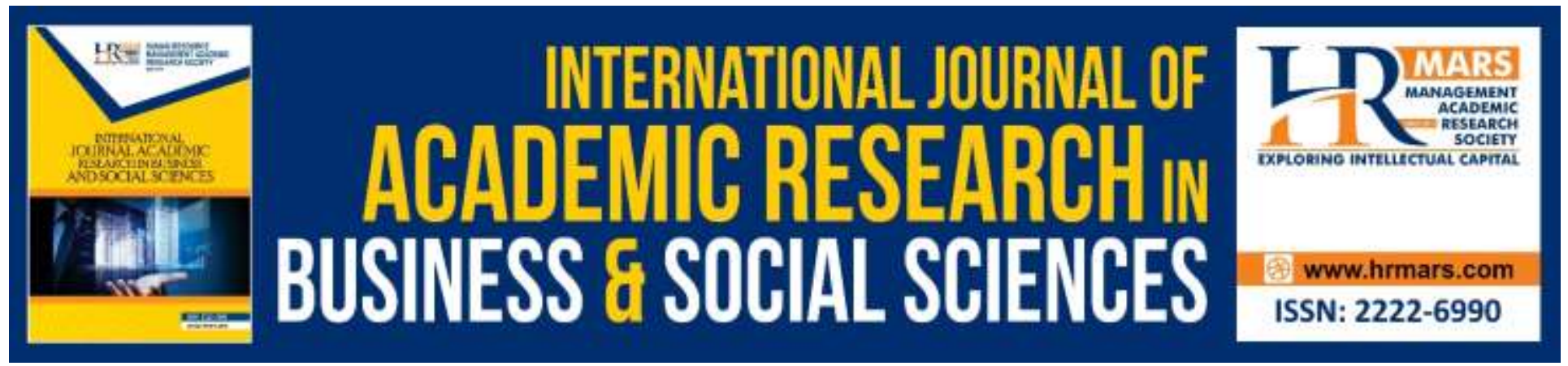

\title{
Impact of Organization Politics on Organization Citizenship Behavior
}

\author{
Muhammad Zia ud Din, Bushra Iram, Fiza Farooq
}

To Link this Article: http://dx.doi.org/10.6007/IJARBSS/v8-i8/4435

DOI: $10.6007 /$ IJARBSS/v8-i8/4435

Received: 28 June 2018, Revised: 21 July 2018, Accepted: 29 July 2018

Published Online: 21 August 2018

In-Text Citation: (Din, Iram, \& Farooq, 2018)

To Cite this Article: Din, M. Z. ud, Iram, B., \& Farooq, F. (2018). Impact of Organization Politics on Organization Citizenship Behavior. International Journal of Academic Research in Business and Social Sciences, 8(8), 6678.

\section{Copyright: (C) 2018 The Author(s)}

Published by Human Resource Management Academic Research Society (www.hrmars.com)

This article is published under the Creative Commons Attribution (CC BY 4.0) license. Anyone may reproduce, distribute, translate and create derivative works of this article (for both commercial and non-commercial purposes), subject to full attribution to the original publication and authors. The full terms of this license may be seen

at: http://creativecommons.org/licences/by/4.0/legalcode

Vol. 8, No. 8, August 2018, Pg. $66-78$

http://hrmars.com/index.php/pages/detail/IJARBSS

JOURNAL HOMEPAGE

Full Terms \& Conditions of access and use can be found at http://hrmars.com/index.php/pages/detail/publication-ethics 


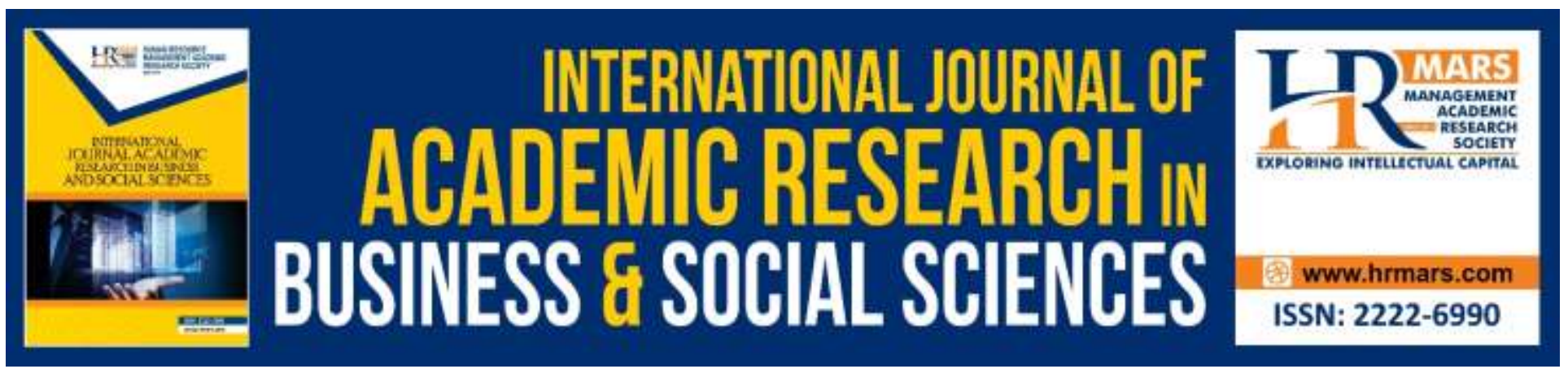

\title{
Impact of Organization Politics on Organization Citizenship Behavior
}

\author{
Muhammad Zia ud Din
}

Lecturer (Department of Public Administration), Government College University Faisalabad Email: zeeyah4@hotmail.com

\section{Bushra Iram}

M.Phill Scholar (Department of Public Administration), Government College University Faisalabad Email: bushrarajpoot602@yahoo.com

\section{Fiza Farooq}

M.Phill Scholar (Department of Public Administration), Government College University Faisalabad Email: farooqfiza3@gmail.com

\begin{abstract}
The purpose of this study is to check the impact of organizational politics on organization citizenship behavior of employees because organizational politics impact on employee behavior. In this study we also check the moderating role of employee engagement in between the relationship of organizational politics and organization citizenship behavior. This study will provide a guideline to numerous leaders or management of an organization in considering the influence of organizational politics on Organization citizenship behavior for attaining organizational goals. This survey is based on questionnaire and data is collected from 125 employee of textile sector organizations located in Faisalabad. The results of this study reveal that organizational politics and organization citizenship behavior are significantly correlated. Results reveal that if Organizational politics will be higher, and then organization citizenship behavior will also be high. Thus, all the hypotheses showed significant results. This study will guide leaders/ Management of organizations to figure out the role of Organizational politics to train employees for the forthcoming cut-throat challenges in international business competition.
\end{abstract}

Keywords: Organizational politics, Organization Citizenship Behavior, Employee Engagement.

\section{Background Information}

According to the international journal of business \& management, Current analyses shown that $66 \%$ research on OCB has occurred since the year 2000 (Podsakoff, Whiting \& Blume 2009). OCBs help to improve the organization efficiency (Organ, 1988; Podsakoff et al., 2009). It increase auspicious psychological climate for both employees and organization (Mena, 2015). According to 
the global journal of management and business research During the second world war, the United States allied military front eighth internal front and advised all its citizens in different areas to enhance efficiency and effectiveness, and make citizen feel that everyone according to his situation are able to attain success, even if citizen away from the battlegrounds where they were distributing pictures had mottoes that everyone is a fighter (Bird \& Rubenstein, 2013). These developments may be that matched with the occurrence of the II World War are motivated by Bernard (1938) in the arrangement of the starts of the term organizational citizenship behavior (to cooperate) (Mehboob \& Bhutto, 2012).

In Pakistan, this research conducted at a very short level. Approximately more than 65 years scholars have been working on employee's supportive types of behaviors. Today organizations are in front of the severe rivalry due to the flow of strong consciousness and information. Therefore the basic purpose of this study is to examine the level of organization citizenship behavior between the university's faculties of Pakistan. Higher education is provided in universities therefore its excellence and proper delivery matters a lot. This study will expose the details due to which particular teachers' expression more helping and sympathetic behavior as compares to others. Contribution of all the individuals those are engaged in coaching and learning is essential for excellence growth. (Odhiambo, 2008). This research is helpful in understanding the impacts of organization politics on organization citizenship behavior (OCB) with the effects of moderator variable employee engagement.

\section{Problem Statement}

Now a day's organizations are striving towards decentralization and employees of the organizations are expecting their leaders should show cooperation role. Now there is a need to improve the organization performance to meet their competitors especially in the textile sector of Pakistan. There is a need to reduce the level of politics, abusive supervision, gender discrimination and work place bulling within organizations to enhance the organization efficiency towards achieving the organization's objectives. Lesser the organizational politics in the organization higher will be the organization citizenship behaviour.

\section{Statement of Purpose}

In this context, this research is to establish the effect of organization politics on organization citizenship behavior. Also, this study has great importance especially for industrial sector. It gives direction to executives to increase the level of organization citizenship behavior and organizational trust of workers by preventing negative politics at workplace. This study is helpful for organization to enhance employee engagement and motivation level.

\section{Research Questions}

There are following research questions.

1. What is influence of organizational politics on organizational citizenship behavior in textile industry of Pakistan?

2. What is relationship between organization politics and employee engagement in textile sectors of Pakistan?

3. How organizational politics is relating with organization citizenship behavior in textile sectors of Pakistan?

4. What is the connection between organizational politics and organization citizenship behavior under moderating role of employee engagement in the textile sector of Pakistan? 
INTERNATIONAL JOURNAL OF ACADEMIC RESEARCH IN BUSINESS AND SOCIAL SCIENCES

Vol. 8, No. 8, August 2018, E-ISSN: 2222-6990 @ 2018 HRMARS

\section{Objective of the Study}

There are following objectives of the study.

$>$ To determine the influence of organization politics on organization citizenship behavior in the industrial sectors of Pakistan.

$>$ To inquire the connection between organization politics and employee engagement.

$>$ To investigate how politics is relating with organization citizenship behavior.

$>$ To investigate the relationship among organizational politics and organization citizenship behavior under the moderation role of employee engagement in the textile sector of Pakistan.

\section{Hypothesis}

We formulate the following hypothesis.

$\mathrm{H} 1$ : there is relationship between organization politics and organizational citizenship behavior in the textile sectors of Pakistan.

$\mathrm{H} 2$ : There is a relationship between organization politics and employee engagement.

H3: There is a relationship between organization politics and organization citizenship behavior under the moderating role of employee engagement.

\section{Literature Review}

\section{Organization Citizenship Behavior}

Organization Citizenship Behavior (OCB) plays an important role in increasing organization efficiency (Yen and Neihoff, 2004), in addition it generating short and long-term results for the organization (Joireman et al., 2006; Dick et al., 2006). Past research shown the environment of the institute is meaningfully related to organization citizenship behavior for the reason that environment cause observations between the workers which manipulate workers willingness of hard working and involved with job and must be passionate toward join the organization citizenship behaviors.(Dimitriades,2007). Organization citizenship behavior can be explained as employee's actions that increase objectives of the institute through participating his/her cultural atmosphere (Organ, 1997; Rotundo and Sackett, 2002).

Study on organization citizenship behavior has promoted by Organ (1988), concept of organization citizenship behavior is containing of five different dynamics: Altruism, Conscientiousness, Sportsmanship, Courtesy and Civic Virtue. Understanding on organization citizenship behavior productivity by Polat (2007) exposes that organization citizenship behavior is favorable in various means for both institution and employees. Organization citizenship behaviors batter the worth of facilities; enhance the productivity or presentation of the institution while it minimizes the prices. Improvement of organization citizenship behavior is beneficial for administrators for the reason that they influence on institutional results or performance (Gonza'lez \& Garazo, 2006). Organization citizenship behavior mostly describe the workers' willingness provide their determination and collaborate with the institution in order to participate in the output, worker happiness, consumer happiness, and excellence. Better-quality organization citizenship behavior denotes workers' availability and passion to skills changes for the effectively carrying out to novel practices of administration (Jung \& Hong, 2008).Organizations understand is that for living in this modest situation organization need to improve the worker determinations or for active working in the organization worker determinations are needed which can be away from the formal desires of the role. (Garg \& Rastogi, 2006). Employees engaging in OCBs reflect their satisfaction with 
INTERNATIONAL JOURNAL OF ACADEMIC RESEARCH IN BUSINESS AND SOCIAL SCIENCES

Vol. 8, No. 8, August 2018, E-ISSN: 2222-6990 @ 2018 HRMARS

organization's work environment and as a way of rewarding their organization in return (Bowling, 2010).

\section{Organizational Politics}

Organization politics refers to actions taken by employees of an organization to obtain, improve and use authority for achieving individual goals (Pfeffer, 1981). Researchers describe organization politics negatively as well as neither completely illegal nor legal action (Mintzberg, 1983, 1985; Ferris \& King, 1991). Organization politics is considered as the enemy of any organization, which is very crucial for both employees and organizations.

Mintzberg (1983) defined organization politics as "informal behavior, ostensibly parochial, typically divisive, and above all, in the technical sense, illegitimate" (P 172). Those employees are engaged in organization politics are continuously thoughtful for their benefits, in what manner they can increase their benefits from the marketplace and in the organization climate Ferris et al. 17 and Bozeman et al. 18. Drory19 observed that Resilient and strict judgment reduces influence of organization politics, on other hand in absenteeism of proper decision making and accountability build the uncertain condition in the organization environment or everybody act accordingly his own interpretations20. Organization politics is unavoidable reality of life for the workers which exist at place of work in many organizations. This situation affects employees' performance and its observations of employees by what means they can tackle it, whether is an optimistic ways and bear all the tasks is as pessimistic ways which reason of unhappiness among them. The politics didn't affect in the same way on all workers. Organization politics does not linked to the constructive organization beliefs such as job contentment, institutional commitment it makes the institution less advanced and helpful that reason to raise anxiety and tension and workers turnover.

Organizational politics means intentionally use of different strategies, to gain particular objectives and personal interests which are not defined in the organizational management and to attain defined objectives by the organization, through unceremonious ways (Mayes and Allen 1977, p. 675). Organization politic means definite actions of workers, to obtain specific, personal, or group interests. In other words organizational politics means are criticizing or blaming to others. So, organization politics is supposed such as employee's self-interested attitude, that are sometimes at the expenditure of others and even sometimes, opposing to the benefits of the organization's administration. Sometime employees may obtain benefits by involving in partisan activities, for instance additional salary, upgrade, incentives or prizes (Vigado-Gadot 2007). However, in other words those employees who are engaged in politics at workplace is a wrong activities, in this way they received undeserved advantages by unfair means which harm the equality of administrative practices, justice and equality. Through political behavior, workers may attain specific personal benefits, rewards, and profits. So, organization politics is linked with the scheming, insulting, rebellious, and unlawful means of attaining one's goals.

Organization politics happens mostly in decision-making, upgrading, and recompensing practices. Additionally, politics at the workplace harmful for both individual and organizational effectiveness and performance (Vigoda, 2001). Therefore, employees identify politics in the organization harmful. In this environment, workers may be likely to conduct yourself diplomatically, when there is a definite quantity of ambiguity at workplace, due to absence of guidance and management. In the same way, when employees see politics among colleagues decision making process and management, they respond to it, either by leaving their job and goodbye the organization, pay no attention to the political activities or engaging themselves in their job (Ferris 
INTERNATIONAL JOURNAL OF ACADEMIC RESEARCH IN BUSINESS AND SOCIAL SCIENCES

Vol. 8, No. 8, August 2018, E-ISSN: 2222-6990 @ 2018 HRMARS

and Kacmar, 1992). Ferris et al. (1989) and Kacmar et al. (1999) says that, if workers observe political behavior at the place of work and they cannot arrange or manage it, they know or classify organization politics as a hazard to their safety, calmness and self-respect that source particular harmful results for instance poor practices, determination and efficiency and turnover. According to the Parker et al. (1995) and U. Başar et al. employees' observations of organization politics minimize their observations of modernism efficiency in the in work climate. Cropanzano et al. (1997) described why workers' views about organization politics supported their state of mind resigning and leaving the organization.

\section{Employee Engagement}

Employee engagement is an out-dated subject in present studies (Lee and Ok, 2016. According to Robinson et al. (2004), there is very short theoretical and experimental study on this subject that has become common. Schaufeli et al. (2002), described employee engagement is a psychosomatic phenomenon "as an inspiring, satisfying, work related state of mind that is characterized by energy, commitment, and interest". Workers are full energetic, also are emotionally as well as bodily powerful (Tummers et al., 2016). Employee Engagement is kind of vigour which a person engaged into his/her work, connecting them to improve his/her routine and outcomes (Maslach, 2003). Saks, (2006) employee engagement has been described as is determination of workers to become engaged into his job activities. Engagement is an optimistic behaviour which established in worker by the organization and social support. In different study engagement has been described in different terms such as 'staffs engagement' (Kahn, 1990), 'worker engagement' (Macey and Schneider, 2008), and 'task engagement' (Bakker and Demeroutti, 2008). According to Zia-ud-Din, Shabbir, Asif, Bilal, \& Raza (2017) leadership or Management of an institute play vital role in engagement of level of employee working in the different organizations. 
INTERNATIONAL JOURNAL OF ACADEMIC RESEARCH IN BUSINESS AND SOCIAL SCIENCES

Vol. 8, No. 8, August 2018, E-ISSN: 2222-6990 @ 2018 HRMARS

\section{Conceptual Framework}

Moderating Variable

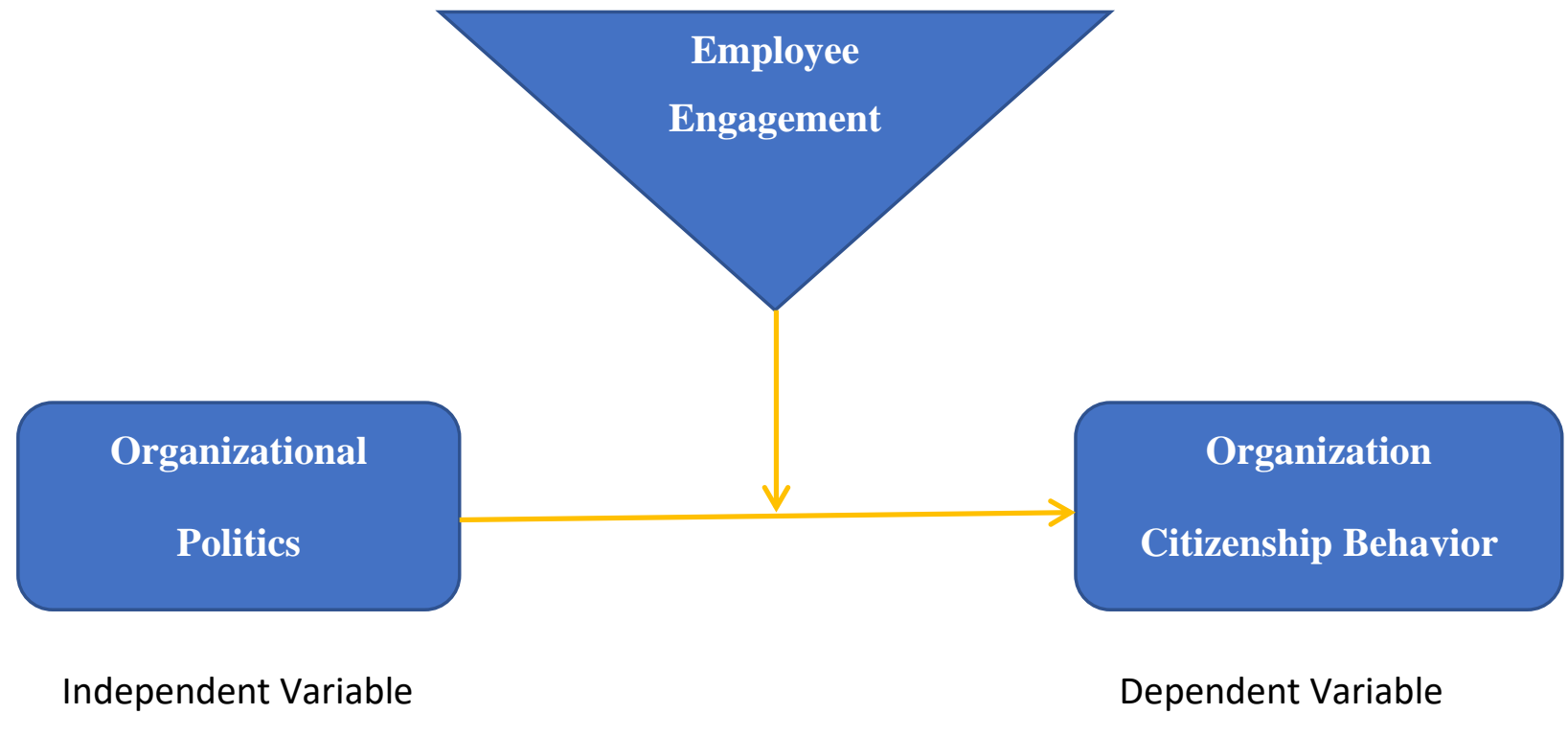

\section{Scales and Questionnaire}

Multiple item scale is used to measure the variables. For first four questions nominal and ordinal scale are used. The Organization Citizenship Behavior is measured with 22 item scale of Smith et al., (1933). The Employee Engagement is measured with 12 item scale of Schaufeli et al. (2001). Organizational Politics is measured with 8 item scale of Kacmar and Carison (1997). We used 5 Likert scale.

\section{Methodology}

For attainment better understanding of the effect of Organization politics on Organization citizenship behavior, nature of study is empirical. The respondents of the study are workers working in the textile sector of Faisalabad.

This study is based on survey data from 125 employees in the textile sector of Faisalabad. The questionnaire is distributed among employees of the textile organizations situated in Faisalabad. The questionnaire is convoyed by a cover letter declaring the aim of study and assuring privacy. Each employee has given one questionnaire. 140 questionnaires are spread amongst the administrators and we received 125 return questionnaires with replying ratio of $89.28 \%$.

To checked the strength of relationship of variable correlation and regression test run. SPSS version 21.0 is used. 


\section{Demographic Factors}

\begin{tabular}{|c|c|c|}
\hline & $\mathrm{F}$ & $\%$ \\
\hline \multicolumn{3}{|l|}{ Gender } \\
\hline Male & 87 & 69.6 \\
\hline Female & 38 & 30.4 \\
\hline \multicolumn{3}{|l|}{ Age } \\
\hline $16-25$ & 41 & 32.8 \\
\hline $26-35$ & 65 & 52 \\
\hline $36-45$ & 11 & 8.8 \\
\hline Above 45 & 8 & 6.4 \\
\hline \multicolumn{3}{|l|}{ Qualification } \\
\hline Matric & 1 & .8 \\
\hline Intermediate & 3 & 2.4 \\
\hline Graduation & 26 & 20.8 \\
\hline Master & 80 & 64 \\
\hline MS/M,phill & 15 & 12 \\
\hline \multicolumn{3}{|l|}{ Department } \\
\hline HRM & 7 & 5.6 \\
\hline Finance & 45 & 36 \\
\hline Marketing & 46 & 36.8 \\
\hline IT & 3 & 2.4 \\
\hline Other & 24 & 19.2 \\
\hline
\end{tabular}

There are 87 male contributors with $69.6 \%$ and 38 participants are female with $30.4 \%$. There are 80 contributors of Master's Degree with $64 \%$ and 26 contributors of graduation with $20.8 \%$. Further 15, 3, and 1 participant of MS/M.Phill, Intermediate and Matric degrees with $15.2 \%$. There are 65 contributors aged between 26-35 with 52\% and 41 participants aged between of 16-25 with $32.8 \%$. Further 11and 8 participants aged between 36-45 and above 45 respectively with cumulatively $15.2 \%$.

For department, there are 46 participants from marketing department with $36.8 \%$ and 45 participants from Finance department with $36 \%$. Further 24, 7 and 3 participants from HRM and IT department respectively with cumulatively $27.2 \%$.

\section{Reliability Test}

\begin{tabular}{cccc}
\hline & $\begin{array}{c}\text { Organization } \\
\text { Citizenship Behavior }\end{array}$ & $\begin{array}{c}\text { Employee } \\
\text { Engagement }\end{array}$ & $\begin{array}{c}\text { Organization } \\
\text { Politics }\end{array}$ \\
\hline Cronbach's Alpha & .887 & .810 & .664
\end{tabular}

Above table show the value of Cronbach's Alpha of Organization Citizenship Behavior, 
INTERNATIONAL JOURNAL OF ACADEMIC RESEARCH IN BUSINESS AND SOCIAL SCIENCES

Vol. 8, No. 8, August 2018, E-ISSN: 2222-6990 C 2018 HRMARS

Employee Engagement and Organization Politics is $0.887,0.810$, and 0.664 . According to the above table value of Cronbach's Alpha is more than 0.7 , so it proves that data is reliable.

\section{Correlations}

\begin{tabular}{|c|c|c|c|c|}
\hline & & & 1 & 2 \\
\hline \multicolumn{5}{|c|}{ Organization Citizenship } \\
\hline \multicolumn{5}{|c|}{ Behavior } \\
\hline \multicolumn{3}{|c|}{ Employee Engagement } & $.665^{* *}$ & \\
\hline \multicolumn{3}{|c|}{ Organization Politics } & $.994^{* *}$ & $.665^{* *}$ \\
\hline \multicolumn{5}{|c|}{${ }^{* *}$. Correlation is positive with the rate of 0.01 levels (2-taile } \\
\hline \multicolumn{5}{|c|}{$*$. Correlation is positive with the rate of 0.05 levels (2-tailec } \\
\hline \multicolumn{5}{|c|}{$\begin{array}{l}\text { Above table shows Organization Citizenship Behavior } \\
\text { engagement with rate of } .665 \text { that is highly significance } \\
\text { Organization Citizenship Behavior is also significantly linked } \\
.994 \text {. Also, Employee Engagement is significantly linked with }\end{array}$} \\
\hline \multicolumn{5}{|c|}{ Regression Analysis } \\
\hline \multicolumn{5}{|c|}{ Model summary } \\
\hline Model & $\mathrm{R}$ & R Square & $\begin{array}{l}\text { Adjusted R } \\
\text { Square }\end{array}$ & $\begin{array}{l}\text { Std. Error of } \\
\text { the Estimate }\end{array}$ \\
\hline 1 & $.994^{\mathrm{a}}$ & .988 & .987 & .06108 \\
\hline
\end{tabular}

a. Predictors: (Constant), Org.P

\section{ANOVA $^{\mathrm{a}}$}

\begin{tabular}{|c|c|c|c|c|c|c|}
\hline \multirow[t]{2}{*}{ Model } & & $\begin{array}{l}\text { Sum of } \\
\text { Squares }\end{array}$ & Df & $\begin{array}{l}\text { Mean } \\
\text { Square }\end{array}$ & $F$ & Sig. \\
\hline & Regression & 36.426 & 1 & 36.426 & 9762.630 & $.000^{\mathrm{b}}$ \\
\hline \multirow[t]{2}{*}{1} & Residual & .459 & 123 & .004 & & \\
\hline & Total & 36.885 & 124 & & & \\
\hline
\end{tabular}

a. Dependent Variable: Org.CB

b. Predictors: (Constant), Org.P

\section{Coefficients}

\begin{tabular}{llrrrrr} 
Model & \multicolumn{2}{c}{$\begin{array}{c}\text { Unstandardized } \\
\text { Coefficients }\end{array}$} & \multicolumn{2}{c}{$\begin{array}{c}\text { Standardized } \\
\text { Coefficients }\end{array}$} & t & Sig. \\
& B & Std. Error & Beta & & \\
\multirow{2}{*}{1} & (Constant) & -.048 & .040 & & -1.192 & .236 \\
& Org.P & 1.007 & .010 & .994 & 98.806 & .000 \\
\hline
\end{tabular}

a. Dependent Variable: Org.CB 
INTERNATIONAL JOURNAL OF ACADEMIC RESEARCH IN BUSINESS AND SOCIAL SCIENCES

Vol. 8, No. 8, August 2018, E-ISSN: 2222-6990 @ 2018 HRMARS

In Table value of $\mathrm{R}$ sequre depicts that Organization Politics has taking $98.8 \%$ variation in Organization Citizenship Behavior which shows that a good impact of organization politics on Organization Citizenship Behavior.

$\mathrm{Y}=\mathrm{bo}+\mathrm{bX}$

Organization Citizenship Behavior $=-0.48+(1.007)$ (Organization Politics)

It means one unit change in organization politics get 0.959 units change in Organization citizenship behavior.

Run MATRIX procedure:

$* * * * * * * * * * * * *$ PROCESS Procedure for SPSS Release $2.16 .3 * * * * * * * * * * * * * * * * * *$

Written by Andrew F. Hayes, Ph.D. www.afhayes.com

Documentation available in Hayes (2013). www.guilford.com/p/hayes3

$$
\begin{gathered}
\text { Model }=1 \\
Y=\text { Org.CB } \\
X=\text { Org.P } \\
M=\text { Emp.E }
\end{gathered}
$$

Sample size

125

$* * * * * * * * * * * * * * * * * * * * * * * * * * * * * * * * * * * * * * * * * * * * * * * * * * * * * * * * * * * * * * * * * * * * * * * * * *$

Outcome: Org.CB

Model Summary

$\begin{array}{ccccccc}R & \mathrm{R}-\mathrm{sq} & \mathrm{MSE} & \mathrm{F} & \mathrm{df1} & \mathrm{df2} & \mathrm{p} \\ .6674 & .4454 & .1691 & 32.3904 & 3.0000 & 121.0000 & .0000\end{array}$

Model

$\begin{array}{llllccc} & \text { coeff } & \text { se } & \mathrm{t} & \mathrm{p} & \mathrm{LLCl} & \mathrm{ULCl} \\ \text { constant } & 1.4985 & 2.0602 & .7273 & .4684 & -2.5802 & 5.5772 \\ \text { Emp.E } & .6092 & .5025 & 1.2124 & .2277 & -.3856 & 1.6040 \\ \text { Org.P } & -.7902 & 1.2954 & -.6100 & .5430 & -3.3549 & 1.7744 \\ \text { int_1 } & 1678 & .3192 & .5256 & .6001 & -.4642 & .7997\end{array}$

Product terms key:

int_1 Org.P $X \quad$ Emp.E

R-square increase due to interaction(s):

R2-chng $F \quad d f 1 \quad d f 2 \quad p$

$\begin{array}{llllll}\text { int_1 } & .0013 & .2763 & 1.0000 & 121.0000 & .6001\end{array}$ 
INTERNATIONAL JOURNAL OF ACADEMIC RESEARCH IN BUSINESS AND SOCIAL SCIENCES

Vol. 8, No. 8, August 2018, E-ISSN: 2222-6990 @ 2018 HRMARS

Conditional effect of $\mathrm{X}$ on $\mathrm{Y}$ at values of the moderator(s):

$\begin{array}{ccccccc}\text { Emp.E } & \text { Effect } & \text { se } & \mathrm{t} & \mathrm{p} & \mathrm{LLCl} & \mathrm{ULCl} \\ 3.7337 & -.1638 & .1904 & -.8604 & .3913 & -.5407 & .2131 \\ 4.1438 & -.0950 & .1705 & -.5572 & .5784 & -.4325 & .2425 \\ 4.5539 & -.0262 & .2370 & -.1105 & .9122 & -.4953 & .4429\end{array}$

Values for quantitative moderators are the mean and plus/minus one SD from mean. Values for dichotomous moderators are the two values of the moderator.

$* * * * * * * * * * * * * * * * * * * *$ ANALYSIS NOTES AND WARNINGS

Level of confidence for all confidence intervals in output:

95.00

------ END MATRIX -----

\section{Conclusion}

After analysis we reached to the conclusion that organizational Politics positively related with organizational citizenship behavior. Higher the organization politics lower will be the organization citizenship Behavior. We can say that organizational politics would be harmful in organizations especially in textile organizational where it reduces the organizational trust within employee and increase trustless environment. This trustless environment consequently decreases citizenship behavior in employees. This study makes contribution to ongoing research on Organization citizenship behavior. Moreover, this study measures the impact of Organization politics on organization citizenship behavior with the catalyst of employee engagement in textile sector organizations of Pakistan. Results shows that employee engagement moderates the relationship between the organization politics and organization citizenship behavior i.e. when engagement among employee is high then organization politics is less harmful for organization citizenship behavior.

\section{Study Limitations}

The present study examined that organization politics is key element in organizational setup. The main purpose of this study is to discover the influence of organizational politics on organizational citizenship behavior in textile organization. Finally additional work is needed to extend research in various towns to find out the result of organization politics in allover Pakistan. Future research may also wish to explore other variable that may predict organization politics such as crisis communication and so on to extend and elaborate on this study's limitations. The future research might comprise on the sample of purely female/ male respondents and examine how it affects organization citizenship behavior on that particular gender. 
INTERNATIONAL JOURNAL OF ACADEMIC RESEARCH IN BUSINESS AND SOCIAL SCIENCES

Vol. 8, No. 8, August 2018, E-ISSN: 2222-6990 @ 2018 HRMARS

\section{References}

Aycan, Z., Kanungo, R., Mendonca, M., Yu, K., Deller, J., Stahl, G., \& Kurshid, A. (2000). Impact of culture on human resource management practices: A 10-country comparison. Applied Psychology, 49(1), 192-221.

Cohen, A., Vigoda, E., \& Samorly, A. (2001). Analysis of the mediating effect of personal-psychological variables on the relationship between socioeconomic status and political participation: $A$ structural equations framework. Political Psychology, 22(4), 727-757.

Dimitriades, Z. S. (2007). The influence of service climate and job involvement on customer-oriented organizational citizenship behavior in Greek service organizations: a survey. Employee Relations, 29(5), 469-491.

Ehrhart, M. G. (2004). Leadership and procedural justice climate as antecedents of unit-level organizational citizenship behavior. Personnel psychology, 57(1), 61-94.

Ferris, G. R., \& Kacmar, K. M. (1992). Perceptions of organizational politics. Journal of management, 18(1), 93-116.

Garg, P., \& Rastogi, R. (2006). New model of job design: motivating employees' performance. Journal of management Development, 25(6), 572-587.

Keen, S. C., Meliza, C. D., \& Rubenstein, D. R. (2013). Flight calls signal group and individual identity but not kinship in a cooperatively breeding bird. Behavioral Ecology, 24(6), 1279-1285.

Macey, W. H., \& Schneider, B. (2008). The meaning of employee engagement. Industrial and organizational Psychology, 1(1), 3-30.

Mayes, B. T., \& Allen, R. W. (1977). Toward a definition of organizational politics. Academy of management review, 2(4), 672-678.

Mehboob, F., Sarwar, M. A., \& Bhutto, N. A. (2012). Factors affecting job satisfaction among faculty member. Asian Journal of Business and Management Sciences, 1(12), 1-9.

Mintzberg, H. (1983). The case for corporate social responsibility. Journal of Business Strategy, 4(2), 3-15.

Odhiambo, N. M. (2008). Financial depth, savings and economic growth in Kenya: A dynamic causal linkage. Economic Modelling, 25(4), 704-713.

Organ, D. W. (1988). Issues in organization and management series. Organizational citizenship behavior: The good soldier syndrome. Lexington, MA, England: Lexington Books/D. C. Heath and Com.

Podsakoff, N. P., Whiting, S. W., Podsakoff, P. M., \& Blume, B. D. (2009). Individual-and organizational-level consequences of organizational citizenship behaviors: A metaanalysis. Journal of applied Psychology, 94(1), 122.

Podsakoff, P. M., MacKenzie, S. B., Paine, J. B., \& Bachrach, D. G. (2000). Organizational citizenship behaviors: A critical review of the theoretical and empirical literature and suggestions for future research. Journal of management, 26(3), 513-563.

Polat, S. (2009). Organizational citizenship behavior (OCB) display levels of the teachers at secondary schools according to the perceptions of the school administrators. Procedia-Social and Behavioral Sciences, 1(1), 1591-1596.

Rotundo, M., \& Sackett, P. R. (2002). The relative importance of task, citizenship, and counterproductive performance to global ratings of job performance: A policy-capturing approach. Journal of applied psychology, 87(1), 66. 
INTERNATIONAL JOURNAL OF ACADEMIC RESEARCH IN BUSINESS AND SOCIAL SCIENCES

Vol. 8, No. 8, August 2018, E-ISSN: 2222-6990 @ 2018 HRMARS

Varela González, J., \& García Garazo, T. (2006). Structural relationships between organizational service orientation, contact employee job satisfaction and citizenship behavior. International Journal of Service Industry Management, 17(1), 23-50.

Vigoda-Gadot, E. (2007). Leadership style, organizational politics, and employees' performance: An empirical examination of two competing models. Personnel Review, 36(5), 661-683.

Zia-ud-Din, M., Shabbir, M. A., Asif, S. B., Bilal, M., \& Raza, M. (2017). Impact of Strategic Leadership on Employee Performance. International Journal of Academic Research in Business and Social Sciences, 7(6), 8-22. 